\title{
Nasopharyngeal colonization by Streptococcus pneumoniae in children with sickle cell disease receiving prophylactic penicillin
}

\author{
Patricia B. Blum Fonseca, ${ }^{1}$ Josefina Aparecida P. Braga, ${ }^{2}$ \\ Antônia Maria de 0 . Machado, ${ }^{3}$ Maria Cristina de C. Brandileone, ${ }^{4}$ Calil Kairalla Farhat $^{5}$
}

\begin{abstract}
Objectives: To determine the prevalence of nasopharyngeal pneumococcus colonization in children with sickle cell disease undergoing penicillin prophylaxis, to identify risk factors for colonization and to serotype and determine antibiotic resistance in pneumococci obtained from those children.

Methods: Between April 9, 2002 and February 28, 2003, 188 nasopharyngeal swabs were obtained from 98 children with sickle cell disease in follow-up at the Hospital São Paulo - Universidade Federal de São Paulo. Pneumococci were isolated and identified by standard methods. The minimal inhibitory concentration for penicillin was determined by the E-test method. Isolates were serotyped with the use of type-specific antisera for 46 different serotypes (Neufeld-Quellung reaction).

Results: The age of children ranged from 4 months to 17 years (median and standard deviation $6.8 \pm 4.7$ years). Thirteen of the 98 children had nasopharyngeal pneumococcus colonization ( $13.3 \%$ prevalence). There was a significantly greater risk of colonization among children less than 2 years old $(p=0.02)$. Twenty-one percent of isolates had intermediate penicillin resistance. There were no isolates highly resistant to penicillin. All isolates were susceptible to erythromycin, ceftriaxone, or vancomycin. The most frequently identified serotypes were $18 \mathrm{C}$ and $23 \mathrm{~F}$.

Conclusions: Penicillin prophylaxis reduced pneumococcal nasopharyngeal colonization and did not increase the prevalence of penicillin-resistant pneumococci in children with sickle cell disease. Penicillin can be used not only for prophylaxis, but also in the acute management of febrile states with these children.
\end{abstract}

J Pediatr (Rio J). 2005;81(2):149-54: Sickle cell anemia, pneumococcal infection, antibiotic-resistance.

\section{Introduction}

Several different studies have confirmed the relation between nasopharyngeal colonization and the risk of developing an invasive infection by Streptococcus

1. MSc, Universidade Federal de São Paulo - Escola Paulista de Medicina (UNIFESP/EPM), São Paulo, SP, Brazil.

2. Professor, Department of Pediatrics, UNIFESP/EPM, São Paulo, SP, Brazil.

3. PhD, UNIFESP/EPM, São Paulo, SP.

4. PhD, UNIFESP/EPM. Coordinator of the SIREVA Project (Regional Vaccination System Project)

5. Professor, Department of Pediatrics, UNIFESP/EPM, São Paulo, SP. Funding agency: FAPESP (process 2001/02501-0)

Manuscript received Aug 12 2004, accepted for publication Dec 222004.

Suggested citation: Fonseca PB, Braga JA, Machado AM, Brandileone MC, Farhat CK. Nasopharyngeal colonization by Streptococcus pneumoniae in children with sickle cell disease receiving prophylactic penicillin. J Pediatr (Rio J). 2005;81:149-54. pneumoniae. ${ }^{1,2}$ The prevalence of nasopharynx colonization by this bacteria can be influenced by many different factors, such as age, geographical area, study population, attendance at day care and prophylaxis with penicillin for children with sickle-cell disease. ${ }^{3,4}$

The rate of nasopharyngeal colonization in Brazil varies from 30 to $50 \%$ in children, 5,6 but we could not find any Brazilian studies that assessed children with sickle-cell anemia. In the United States (USA), the rate of nasopharyngeal colonization among such patients varies from 5 to $17 \%$, and these results cannot be extrapolated for a different population. $3,7,8$

In the general population, Streptococcus pneumoniae resistance to penicillin is becoming ever more common and is a cause of concern all over the world. ${ }^{9}$ This concern increases with relation to children with sickle-cell anemia 
who are exposed to prolonged penicillin usage in order to reduce the risk of pneumococcal infection, ${ }^{10}$ which could result in the selection of strains resistant to this antimicrobial. ${ }^{11,12}$

Reported pneumococcus resistance to penicillin in Brazil has varied from 15 to $36 \%$ for strains isolated from invasive disease sufferers, with similar rates being found among colonizing strains and almost all of such strains having an intermediate level of penicillin resistance. 5,6,13,14

Studies undertaken with the objective of assessing pneumococcus resistance to penicillin in children with sickle cell disease on prophylaxis with this antimicrobial have returned conflicting results. Anglin et al. ${ }^{3}$ found intermediate resistance in $2.9 \%$ of strains isolated from nasopharynx, and Norris et al. ${ }^{7}$ found $33 \%$ penicillin resistance with $36 \%$ of these exhibiting elevated resistance. In neither study was any increased resistance in association with prophylaxis observed. In contrast, Steele et al. ${ }^{8}$ performed a study which found evidence of penicillin resistance in $62 \%$ of strains, while a control group that had not been given penicillin presented $41 \%$ resistance, associating the increased resistance with prophylaxis.

The objectives of the current study are as follows: to evaluate the prevalence of nasopharyngeal colonization by Streptococcus pneumoniae in children with sickle-cell anemia using prophylactic penicillin, to identify risk factors for colonization and to verify the antimicrobial resistance profile and the serotypes of the strains isolated.

\section{Methods}

The sectional study was performed at the Pediatric Hematology Division of the Pediatric Specialties Course run by the Pediatrics Department of the Universidade Federal de São Paulo, Escola Paulista de Medicina (UNIFESP-EPM), Hospital São Paulo, in the period from April 2002 to February 2003. The research protocol was approved by the Committee for Ethics in Research at the Universidade Federal de São Paulo/Hospital São Paulo.

The study population consisted of 98 patients, aged from 4 months to 17 years, whose sickle-cell anemia diagnoses had been confirmed by isoelectric focusing test or by electrophoresis of hemoglobin in alkaline $\mathrm{pH}$, and who had been using antimicrobial prophylaxis with penicillin benzathine or penicillin $\mathrm{V}$, for more than a month. All of the patients were residents of São Paulo state and the majority lived in Greater São Paulo.

Patients were excluded from the study if they did not receive prophylaxis, were allergic to penicillin (and so were on erythromycin) or if they had been given the 7-valent antipneumococcal conjugated vaccine, since the conjugated vaccine reduces nasopharyngeal colonization by the serotypes it contains. ${ }^{15,16}$

At each consultation during the study period (generally every 4 months), held at the Pediatric Hematology Clinic, parents or guardians were interviewed by questionnaires by the researcher. Epidemiological data were obtained at these interviews relating to: (1) the child (age, sex, race, genotype [HbSS, HbSC or HbS-beta thalassemia], attendance at day care or school); (2) prophylaxis (period of use, type of medication and compliance); (3) vaccination (with respect of the 23 -valent polysaccharide pneumococcal vaccine); (4) current infections or infections during the 3 months prior to collecting material from the nasopharynx; (5) current or during the previous 3 months use of antibiotics, with the exception of prophylaxis; (6) hospitalizations during the previous 3 months; (7) living conditions.

Nasopharynx samples were collected during the consultations at the clinic, at minimum intervals of 30 days, by means of sterile swabs with flexible stalks, which were introduced carefully via the children's nostrils to a depth corresponding to two thirds of the distance between their nose and earlobe. ${ }^{17}$ Next the swab was immersed in the appropriate Amies transport medium and sent, 1 to 2 hours after collection, at ambient temperature to the bacteriology section at the Instituto Paulista de Doenças Infecciosas e Parasitárias, affiliated to UNIFESP.

The material was inoculated on plates containing $5 \%$ sheep blood agar. The plates were incubated at $35 \pm 1{ }^{\circ} \mathrm{C}$, with 5 to $10 \% \mathrm{CO}_{2}$, in an atmosphere produced by a candle jar, for 24 hours. The presence of a gray-green zone around colonies (alpha-hemolysis) was presumed to indicate Streptococcus pneumoniae. The agent was confirmed by rapid latex agglutination test and by assessment of the inhibition zone around a disk of optochin and, if necessary a bile solubility test was also performed.

Penicillin susceptibility was assessed by means of the oxacillin disc diffusion method $(1 \mu \mathrm{g})$, with an inhibition zone $\geq 20 \mathrm{~mm}$ considered indicative of susceptibility to penicillin, and a halo $\leq 19 \mathrm{~mm}$, as resistance to penicillin. Minimum inhibitory concentration (MIC) for penicillin was determined by the E-test method for all strains of pneumococcus resistant to oxacillin (halo $\leq 19 \mathrm{~mm}$ ). The MIC for penicillin values were interpreted as susceptible if $\leq 0.06 \mu \mathrm{g} / \mathrm{ml}$, intermediate from 0.1 to $1 \mu \mathrm{g} / \mathrm{ml}$ and as resistant if $\geq 2.0 \mu \mathrm{g} / \mathrm{ml}^{18}$ Bacterial resistance to erythromycin, cotrimoxazole, levofloxacin, ceftriaxone and vancomycin were also determined by the E-test.

Serotyping of the isolated pneumococcus strains was performed at the Instituto Adolfo Lutz by means of the Neufeld-Quellung reaction using antisera produced at the Statem Serum Institute, in Copenhagen, Denmark.

A descriptive analysis was performed of the profiles of the patients and pneumococcus strains. In order to test the significance of differences between the subsets of colonized and uncolonized children Pearson's chi-square test was applied. The descriptive cutoff $(p)<0.05$ or $5 \%$ was considered statistically significant for rejecting the equality hypothesis.

\section{Results}

Ninety-eight patients with sickle-cell anemia were enrolled, with ages varying from 4 months to 17 years, giving mean and standard deviation of $6.8 \pm 4.7$ years, with 
23 children ( $23.5 \%)$ aged $\leq 24$ months, 22 (22.5\%) from 25 to 71 months and $53(54 \%) \geq 72$ months of age. Genotypes were as follows: 69 patients $(70.4 \%)$ had sickle-cell anemia (HbSS), 18 (18.4\%) were HbSC carriers, and 11 (11.2\%), had HbS-beta thalassemia.

With respect of the type of prophylaxis, 82 patients $(83.7 \%)$ were using penicillin benzathine and $16(16.3 \%)$ penicillin $\mathrm{V}$. The duration of prophylaxis varied from 1 month to 14 years, with a mean of $4.4 \pm 3.4$ years. With respect of compliance with prophylaxis, it was observed that 72 patients $(73.5 \%)$ claimed that they took their medication regularly. The 23 -valent antipneumococcal polysaccharide vaccine had been given to 68 children (69.4\%).

Pneumococcus was isolated from the nasopharynx of 13 of the 98 children, equating to a colonization rate of $13.3 \%$ ( $95 \% \mathrm{CI}: 7$ to $22 \%$ ). Just one nasopharynx material sample was collected from 28 of the children, two samples from 50 children and three samples from 20 children. A total of 188 samples from the nasopharynx were obtained, of which 14 were positive for pneumococcus, isolating the agent from $7.4 \%$ ( $95 \% \mathrm{CI}: 4$ to $12 \%$ ) of the swabs. One of the 13 colonized children, therefore, provided two samples that were positive for Streptococcus pneumoniae.

Just one child $(1 / 13,7.7 \%)$ presented sinusitis after the nasopharynx culture presented pneumococcus, five patients $(38.5 \%)$ had no infection after the bacteria was isolated, with the next sample being negative, and seven (53.8\%) did not return to the clinic after the positive sample.

Age was the only risk factor for colonization, with patients aged $\leq 24$ months being most colonized $(7 / 13=30.4 \%)$ compared to the other age groups. No other risk factors for nasopharyngeal colonization were identified (Table 1 ).

Five of the 14 strains isolated (35.7\%) exhibited resistance to screening with oxacillin discs. The results of the MIC evaluation showed that three of the five strains tested exhibited intermediate penicillin resistance, all with an MIC of $0.25 \mu \mathrm{g} / \mathrm{ml}$, which is equivalent to a resistance rate of $21.4 \%(3 / 14)$. No strains with elevated resistance to penicillin were observed. Of the 98 children assessed, three ( $3.1 \%)$ had been colonized by resistant strains. No resistance was observed to erythromycin, ceftriaxone or vancomycin. Nine strains $(64.3 \%)$ were resistant to cotrimoxazole and six $(42.9 \%)$, to levofloxacin.

Thirteen of the 14 strains isolated from the 13 colonized patients were serotyped. The serotypes found and their respective susceptibilities to penicillin are listed in Table 2 .

\section{Discussion}

Since the first studies of Streptococcus pneumoniae colonization were performed, authors have been concluding that the rate of isolation of the bacteria and, as a result, the identification of carrier status depend, in addition to other factors, on the methodology utilized. In 1996, Norris et al. ${ }^{7}$ assessed colonization by pneumococcus in children with sickle-cell anemia, obtaining material with swabs of the nasopharynx or oropharynx, and found that the number of samples positive for Streptococcus pneumoniae was significantly greater when the material was obtained from the nasopharynx. Based on this data our study employed samples taken from the nasopharynx.

It was in 1984 that Anglin et al. ${ }^{3}$ published the first study to assess the effect of prophylactic penicillin on nasopharyngeal colonization and found a prevalence of $11.1 \%$ among sickle-cell sufferers and $37.1 \%$ in a control group with no prophylaxis. Other authors have found colonization rates of children with sickle-cell anemia using penicillin that vary from 8 to $15.5 \%, 7,19,20$ In our study we found results comparable to these, with a colonization rate of $13.3 \%$. Nevertheless, we should point out that the majority of our patients used penicillin benzathine, in contrast with all these studies in which the patients were on oral penicillin $\mathrm{V}$.

If we compare the prevalence of colonization found in this study with that of others also performed in Brazil, but involving children without sickle-cell anemia, we find that our patients have a lower rate of colonization. In São Paulo, the rate of pneumococcal colonization of children under 5 years of age was $34.8 \% 5$ and, in Fortaleza it was $55 \% .^{6}$ It we consider just the children under 72 months old in our study we observe a prevalence of $20 \%$, which is lower than that found in these studies involving normal children, suggesting that the prophylaxis with penicillin benzathine reduced colonization by Streptococcus pneumoniae.

Several different studies have shown that the age of the child interferes with the prevalence Streptococcus pneumoniae colonization, with more colonization of children less than 2 years of age.4,21,22 Studying children with sickle-cell anemia, Steele et al. ${ }^{8}$ observed $33 \%$ colonization of children less than 2 years old, $10 \%$ for those between 2 and 5 years and $6 \%$ above 5 years, which results are very similar to those found by Norris et al. ${ }^{7}$ and in the present study. This confirms that patients less than 2 years old have a greater risk of colonization.

Compliance with antimicrobial prophylaxis did not have any influence on the prevalence of colonization, which is probable the result of the small number of colonized patients in the study, to the method used to assess compliance and to interference by other variables such as patient age. ${ }^{4,22}$

Immunization with the 23-valent polysaccharide antipneumococcal vaccine appears not to reduce the prevalence of nasopharyngeal colonization by Streptococcus pneumoniae, ${ }^{23}$ in common with what we observed in our study; some immunized children had been colonized by serotypes in the vaccine.

The presence of other children less than 5 years old at home and attendance at day care centers are risk factors for colonization. 5,6,24 We did not find the same result, probably due to the low number of patients with siblings less than 5 years old and the low percentage of patients under 6 years old who attend day care or school in our study.

We did not verify any increased pneumococcal penicillin resistance when we compared our data with a number of different studies performed in Brazil, involving both invasive 
and colonizing strains; $5,6,13,14$ this would appear to indicate that penicillin is still safe both for prophylaxis and for initial treatment of febrile episodes in anemic children.

Around 50 to $80 \%$ of penicillin-resistant strains are also resistant to cotrimoxazole. ${ }^{5,14}$ The high frequency of resistance to cotrimoxazole that has been observed in a number of different studies (63 to $81 \%$ ), including ours, rules out the use of this antibiotic for the treatment of pathologies of which pneumococcus is the principal etiologic agent. In our sample we found $42.9 \%$ of strains were

Table 1 - Risk factors among children with sickle cell disease colonized or not with Streptococcus pneumoniae

\begin{tabular}{|c|c|c|c|}
\hline Risk factor & $\begin{array}{c}\text { n colonized } \\
\text { total = } 13 \\
n(\%)\end{array}$ & $\begin{array}{c}\text { n non-colonized } \\
\text { total }=85 \\
n(\%)\end{array}$ & $\mathbf{p}$ \\
\hline \multicolumn{4}{|l|}{ Age } \\
\hline$\leq 24$ months & $7(30.4 \%)$ & $16(69.6 \%)$ & $0.02 *$ \\
\hline 25 to 71 months & $2(9.1 \%)$ & $20(90.9 \%)$ & \\
\hline$\geq 72$ months & $4(7.5 \%)$ & $49(92.5 \%)$ & \\
\hline \multicolumn{4}{|l|}{ Genotype } \\
\hline$S S$ e $S B$ & $11(13.8 \%)$ & $69(86.2 \%)$ & 0.77 \\
\hline SC & $2(11.1 \%)$ & $16(88.9 \%)$ & \\
\hline \multicolumn{4}{|l|}{ Prophylaxis } \\
\hline Penicillin V & $11(13.4 \%)$ & $71(86.6 \%)$ & 0.92 \\
\hline Penicillin benzathine & $2(12.5 \%)$ & $14(87.5 \%)$ & \\
\hline \multicolumn{4}{|l|}{ Compliance } \\
\hline Regular & $12(16.7 \%)$ & $60(83.3 \%)$ & 0.19 \\
\hline Irregular & $1(3.8 \%)$ & $25(96.2 \%)$ & \\
\hline \multicolumn{4}{|l|}{ Pneumo-23 Vaccine } \\
\hline Yes & $6(8.8 \%)$ & $62(91.2 \%)$ & 0.10 \\
\hline No & $7(23.3 \%)$ & $23(76.7 \%)$ & \\
\hline \multicolumn{4}{|c|}{ Children under 5 years at home } \\
\hline Yes & $3(9.1 \%)$ & $30(90.9 \%)$ & 0.58 \\
\hline No & $10(15.4 \%)$ & $55(84.6 \%)$ & \\
\hline \multicolumn{4}{|c|}{$\begin{array}{l}\text { Children under } 6 \text { years }(n=52) \\
\text { in day care centers or schools }\end{array}$} \\
\hline Yes & $2(22.2 \%)$ & $7(19.4 \%)$ & 0.85 \\
\hline No & $7(77.8 \%)$ & $36(80.6 \%)$ & \\
\hline
\end{tabular}

* Chi-square test with two degrees of freedom.

Table 2 - Serotypes found, age and vaccines according to the colonized patient and susceptibility to penicillin of the 14 isolated strains

\begin{tabular}{ccccc}
\hline $\begin{array}{c}\text { Patient } \\
\mathbf{n}\end{array}$ & Serotype & Age & $\begin{array}{c}\text { 23-valent } \\
\text { vaccine }\end{array}$ & $\begin{array}{c}\text { Penicillin } \\
\text { susceptibility }\end{array}$ \\
\hline 1 & $18 \mathrm{C}$ & 22 months & no & $\mathrm{S}$ \\
2 & $23 \mathrm{~F}$ & 5.4 years & yes & $\mathrm{S}$ \\
2 & $*$ & 5.7 years & yes & $\mathrm{S}$ \\
3 & $6 \mathrm{~B}$ & 8.8 years & yes & $\mathrm{I}$ \\
4 & $\mathrm{NT}$ & 7 years & yes & $\mathrm{S}$ \\
5 & $19 \mathrm{~F}$ & 10 months & no & $\mathrm{S}$ \\
6 & $10 \mathrm{~A}$ & 7.8 years & yes & $\mathrm{I}$ \\
7 & $\mathrm{NT}$ & 9 years & yes & $\mathrm{S}$ \\
8 & $23 \mathrm{~B}$ & 5.3 years & no & $\mathrm{I}$ \\
9 & $19 \mathrm{~A}$ & 20 months & no & $\mathrm{S}$ \\
10 & $6 \mathrm{~A}$ & 6 months & no & $\mathrm{S}$ \\
11 & $23 \mathrm{~F}$ & 10 months & no & \\
12 & 33 & 7 months &
\end{tabular}

* No serotyping performed; NT = non-serotyped by the method; $\mathrm{S}=$ sensitive; I = intermediate resistance. 
resistant to levofloxacin, which conflicts with published literature in which $99 \%$ of pneumococcus strains isolated were sensitive to this antimicrobial. ${ }^{25}$ Despite our sample being small, this result indicates greater than expected resistance. The frequency of pneumococcal resistance to ceftriaxone remains low, with rates varying from 0 to $8 \%$ depending on location. $5,6,13,19$ In the entirety of the literature evaluated to date, there are no pneumococcus strains resistant to vancomycin.

The number of strains isolated from our population was small, and as such the true prevalence of the serotypes cannot be determined. The majority of the strains found $(69.2 \%)$ in our population were members of the principle serotypes responsible for invasive disease in Brazil. 26 With respect of serogroups, we observed that the most frequent were $23(23.1 \%), 6(15.4 \%), 19$ $(15.4 \%)$ and $18(15.4 \%)$, similar values to those found in developed countries, since serogroups 6, 14, 19 and 23 predominate in the infections of children all over the world, and 18 in developed countries. ${ }^{27}$ Infections caused by serotypes 1 and 5 are common in our country, ${ }^{27}$ and probably were not isolated because they are not very common in nasopharyngeal colonization. ${ }^{28}$ These data confirm the usefulness of studying nasopharyngeal colonization for monitoring the profile of invasive strains.

We conclude that both prophylaxis with oral penicillin $\mathrm{V}$ and with penicillin benzathine contribute to reducing nasopharyngeal colonization of sickle-cell patients, although those younger than 24 months of age remain at greater risk of colonization, despite prophylaxis, and also that prolonged penicillin use does not result in an increase in pneumococcus resistance to this antimicrobial, and appears to retain its efficacy.

\section{References}

1. Gray BM, Coverse GM, Dillon HC. Epidemiological studies of Streptococcus pneumoniae in infants: acquisition, carriage and infection during the first 24 months of life. J Infect Dis. 1980;142:923-33.

2. Lloyd-Evans N, O'Dempsey TJ, Baldeh I, Secka O, Demba E, Todd $\mathrm{JE}$, et al. Nasopharyngeal carriage of pneumococci in Gambian children and their families. Pediatr Infect Dis $\mathrm{J}$. 1996;15:866-71.

3. Anglin DL, Siegel JD, Pacini DL, Smith SJ, Adams G, Buchanan GR. Effect of penicillin prophylaxis on nasopharyngeal colonization with Streptococcus pneumoniae in children with sickle cell anemia. J Pediatr. 1984;104:18-22.

4. Dagan R, Leibovitz E, Greenberg D, Yagupsky P, Fliss DM, Leiberman A. Dynamics of pneumococcal nasopharyngeal colonization during the first days of antibiotic treatment in pediatric patients. Pediatr Infect Dis J. 1998;17:880-5.

5. Ferreira LLM, Carvalho ES, Berezin EN, Brandileone MC. Colonização e resistência antimicrobiana de Streptococcus pneumoniae isolado em nasofaringe de crianças com rinofaringite aguda. J Pediatr (Rio J). 2001;77:227-34.

6. Rey LC, Wolf B, Moreira LB, Verhoef J, Farhat CK. S. pneumoniae isolados da nasofaringe de crianças sadias e com pneumonia: taxa de colonização e suscetibilidade aos antimicrobianos. J Pediatr (Rio J). 2002;78:105-12.
7. Norris CF, Mahannah SR, Smith-Witley K, Frempong KO, McGowan KL. Pneumococcal colonization in children with sickle cell disease. J Pediatr. 1996;129:821-7.

8. Steele RW, Warrier R, Unkel PJ, Foch BJ, Howes RF, Shah S, et al. Colonization with antibiotic-resistant Streptococcus pneumoniae in children with sickle cell disease. J Pediatr. 1996; 128:531-5.

9. Klugman KP. Pneumococcal resistance to antibiotics. Clin Microbiol Rev. 1990;3:171-96.

10. Gaston MH, Verter JI, Woods G, Pegelow C, Kelleher J, Presbury $G$, et al . Prophylaxis with oral penicillin in children with sickle cell anemia: a randomized trial. N Engl J Med. 1986;314:1593-9.

11. Appelbaum PC. Epidemiology and in vitro susceptibility of drugresistant Streptococcus pneumoniae. Pediatr Infect Dis J. 1996; 15:932-9.

12. Tomasz A. Antibiotic resistance in Streptococcus pneumoniae. Clin Infect Dis. 1997;24:S85-8.

13. Berezin EN, Carvalho LH, Lopes CR, Sanajotta AT, Brandileone MCC, Menegatti S, et al. Meningite pneumocócica na infância: características clínicas, sorotipos mais prevalentes e prognóstico. J Pediatr (Rio J). 2002;78:19-23.

14. Mantese OC, Paula A, Moraes AB, Moreira TA, Guerra MLLS, Brandileone MCC. Prevalência de sorotipos e resistência antimicrobiana de cepas invasivas do Streptococcus pneumoniae. J Pediatr (Rio J). 2003;79:537-42.

15. Dagan R, Melamed R, Muallen M, Piglausky L, Greenberg D, Abramson $O$, et al. Reduction of nasopharyngeal carriage of pneumococci during the second year of life by a heptavalent conjugate pneumococcal vaccine. J Infect Dis. 1996; 174:1271-8.

16. Mbelle N, Huerbner RE, Wasas AD, Kimura A, Chang I, Klugman KP. Immunogenicity and impact on nasopharyngeal carriage of a nonvalent pneumococcal conjugate vaccine. J Infect Dis. 1999;180:1171-6.

17. World Health Organization (WHO), Centers of Disease Control (CDC). Manual for the National surveillance of antimicrobial resistance of Streptococcus pneumoniae and Haemophilus influenzae: epidemiological and microbiological methods. August, 1994. Available from: http://www.who.int/chd/publications/ ari/bact/bact.htm

18. National Committee for Clinical Laboratory Standards. Performance standards for antimicrobial susceptibility testing; twelfth informational supplement. NCCLS, 22(1). Document M100- S12. Wayne, Pennsylvania: NCCLS, 2002.

19. Woods GM, Jorgensen JH, Waclawiw MA, Reid C, Wang W, Pegelow $\mathrm{CH}$, et al. Influence of penicillin prophylaxis on antimicrobial resistance in nasopharyngeal S. pneumoniae among children with sickle cell anemia. J Pediatr Hematol Oncol. 1997; 19:327-33.

20. Sakhalkar VS, Sarnaik AS, Asmar BI, Conner-Warren R, Shurney W, Abdel-Haq NM. Prevalence of penicillin-nonsusceptible Streptococcus pneumoniae in nasopharyngeal cultures from patients with sickle cell disease. South Med J. 2001;94:401-4.

21. Novales MG, Snatos FS, Gallardo HG, Miranda BL, Aviles GE, Barajas MN, et al. Streptococcus pneumoniae: low frequency of penicillin resistance and high resistance to trimetoprimsulfamethoxazole in nasopharyngeal isolates from children in a rural area in Mexico. Arch Med Rev. 1997;28:559-63.

22. Principi N, Marchisio P, Schito GC, Mannnelli S and the Ascanius Project Collaborative Group. Risk factors for carriage of respiratory pathogens in the nasopharynx of health children. Pediatr Infect Dis J. 1999;18:517-23.

23. Wright PF, Sell SH, Vaughn WK, Andrews C, McConnell KB, Schiffman G. Clinical studies of pneumococcal vaccines in infancy. II. Eficacy and effect on nasopharyngeal carriage. Rev Infect Dis. 1981;3 Suppl:S108-12.

24. Dagan R, Melamed R, Muallen M, Piglansky L, Yagupsky P. Nasopharyngeal colonization in Southern Israel with antibioticresistant pneumococci during the first 2 years of life: relation to serotypes likely to be included in pneumococcal conjugate vaccines. J Infect Dis. 1996;174:1352-5.

25. Jones ME, Blosser-Middleton RS, Critchley IA, Thornsberry C, Saham DF, Yamakita J, et al. The activity of levofloxacin and comparator agents against clinical isolates of Streptococcus pneumoniae collect worldwide during 1999 and 2000. Chemotherapy. 2002;48:232-7.

26. Brandileone MC, Di Fabio JL, Vieira VS, Zanella RC, Casagrande ST, Pignatare AC, et al. Geographic distribution pf penicillin resistance of Streptococcus pneumoniae in Brazil: genetic relatedness. Microb Drug Resist. 1998;4:209-17. 
27. Sniadack DH, Schwartz B, Lipman H, Bogaerts J, Butler JC, Dagan $R$, et al. Potential interventions for the prevention of childhood pneumonia: geographic and temporal differences in serotype and serogroup distribution of sterile site pneumococcal isolates from children - implications for vaccine strategies. Pediatr Infect Dis J. 1995;14:503-10.

28. Berezin EN, Cardenuto MD, Otsuka M, Ferreira LL, Guerra ML, Brandileone MC, et al MT. Avaliação do uso de isolados de Streptococcus pneumoniae (SP) de swab de nasofaringe para avaliar resistência bacteriana em crianças de São Paulo. Rev Paul Pediatr. 2003;21:179-85.

\section{Correspondence:}

Patricia Belintani Blum Fonseca

Av. Dr. Altino Arantes, 1000/21, Vila Clementino

CEP 04042-004 - São Paulo, SP

Brazil

Tel.: +55 (11) 5594.5196

Fax: +55 (11) 5078.8195

E-mail: patricia_blum@uol.com.br 